\title{
Writing with heads: animated logographs and syllabograms in Maya writing
}

\author{
Nikolai Grube
}

\begin{abstract}
:
One aspect of Maya hieroglyphic writing that continues to fascinate us is its pronounced figurativeness, which finds its greatest expression in head variants of signs and in full figure glyphs. For a more systematic understanding of these personified signs, it is necessary to divide them into two groups. The first class are "essential personifications". These are logograms that render names of anthropomorphic or zoomorphic beings by depicting their heads or other important parts of their bodies. The second class of personified signs are "unspecific personifications", where there is no natural relationship between sign and meaning. These are most, syllabic signs. The animation of syllabic signs occurs especially in dedication texts. The study of the use and distribution of personified signs helps us to understand the relation between image, anima, and agency in Maya hieroglyphic writing.
\end{abstract}

Keywords: Maya hieroglyphic writing, Maya epigraphy, personifications, animation.

\section{Resumen:}

ESCRIBIR CON CABEZAS: LOGOGRAMAS Y SILABOGRAMAS ANIMADOS EN LA ESCRITURA MAYA

La escritura jeroglifica maya es un sistema de escritura excepcionalmente complejo, que proporciona una visión profunda de los conceptos émicos de comunicación y su conexión con el mundo animado. Un aspecto fascinante de la escritura maya es su figuración pronunciada, que encuentra su máxima expresión en las variantes de cabeza de los signos y en los glifos de figura completa. Para una comprensión más sistemática de estos signos personificados, es necesario dividirlos en dos grupos. La primera clase son "personificaciones esenciales". Estos son logogramas que dan nombres de seres antropomórficos o zoomórficos al representar sus cabezas $u$ otras partes importantes de sus cuerpos. La segunda clase de signos personificados son las "personificaciones genéricas", donde no existe una relación natural entre el signo y el significado. Estos son en su mayoría, signos silábicos. La animación de los signos silábicos ocurre en contextos específicos en donde particularmente necesaria es la presencia de lo sobrenatural. El estudio del empleo y de la distribución de signos personificados permite a nosotros a entender las relaciones que en el pensamiento maya existieron entre la imagen, entre la imagen, animacidad y agencia en el pensamiento maya.

Palabras clave: Escritura jeroglífica maya, epigrafía maya, personificaciones, animación.

Nikolai Grube • University of Bonn, email: ngrube@uni-bonn.de 
There is hardly any aspect of Maya writing that fascinates outsiders and specialists as much as its extraordinary visual complexity. One factor that definitely contributes to the impression of an exuberant visual quality of Maya writing is the fact that Maya scribes had many different calligraphic registers at their disposal that were available to them. This applies in particular to the form of the signs they chose for the creation of a text. Besides abstract signs, scribes had at their disposal signs representing bodies and body parts, but especially heads and faces. Already at the beginning of hieroglyphic research, scholars were amazed to discover that numbers could be written either with bars and dots, or with anthropomorphic signs which today we call personified forms or head variants (Spinden 1913: 80-81; Thompson 1950: 44-45). These are signs depicting the heads of the supernaturals which represented these numbers. In some cities, for example in Copan and Quirigua, scribes went even further and used full-figure hieroglyphs for almost all calendrical elements, including the numbers and the periods of the Long Count (Figure 1). Today we know that full-figure hieroglyphs and head variants existed not only for numbers and the periods of the calendar, but that entire texts could be represented by signs based on images of animals or human beings.

The personification of signs in Maya hieroglyphic writing has received astonishingly little attention in the scholarly debate. One explanation could be the enthusiasm for the decipherment and the linguistic dimension of the written texts,
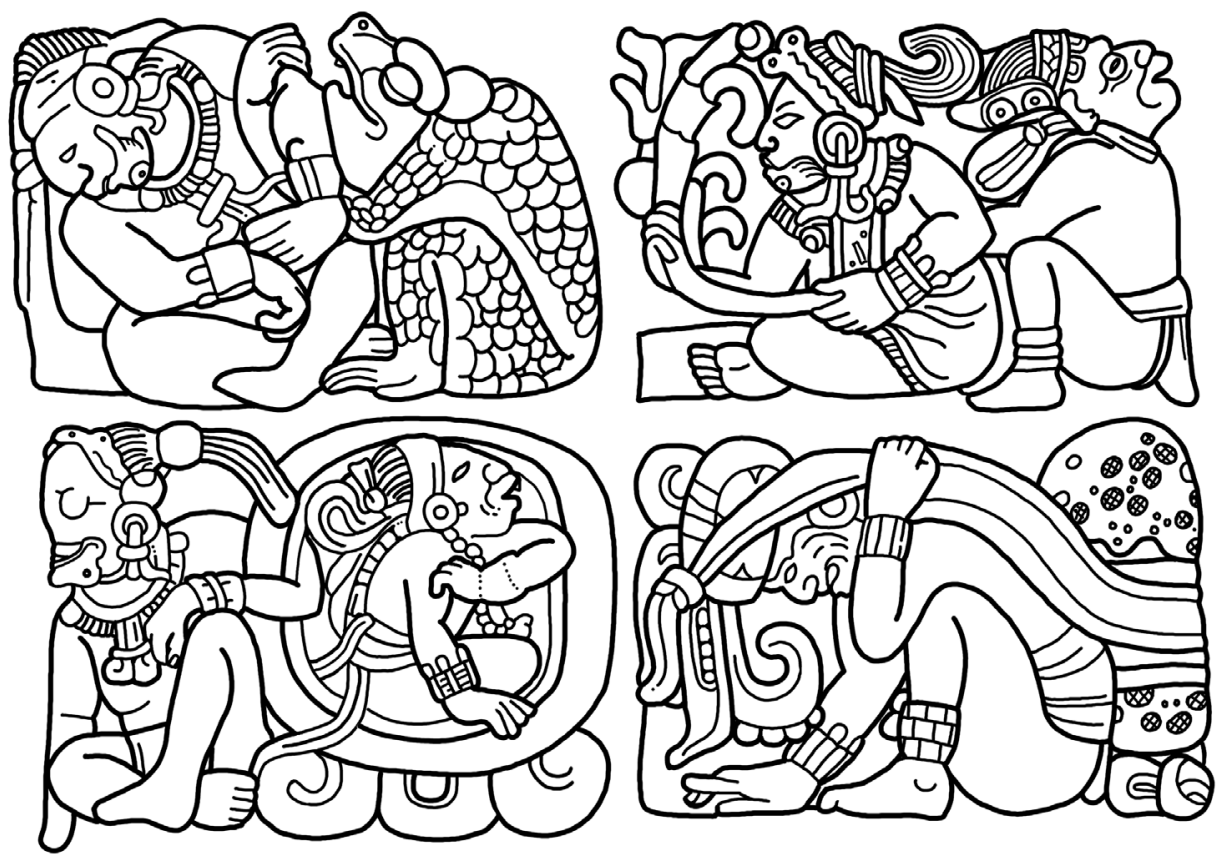

Figure 1: Full figure glyphs on Copan Stela D, A3-B4. (Drawing by Nikolai Grube) 
which has dominated most publications in the past decades. Questions of grammar, the reading of texts, and the analysis of inscriptions and their historical contextualization have been very much in the focus of Maya epigraphy. Only recently other aspects of Maya writing have come to attention. In various recent publications, Stephen Houston has stressed the pictoriality of Maya writing, comparing it to Egyptian hieroglyphs, which likewise preserves its pictorial quality over an enormous period of time (Houston 2014: 75-123; Houston and Stauder 2020). He also points out the porosity between image and texts in these scripts. Hieroglyphic scripts refer to the world outside the texts by preserving a large degree of pictoriality, and not only through their language code. This distinguishes hieroglyphic scripts from other, more abstract "line or stroke based" systems (Houston and Stauder 2020: 9).

Our passion for the linguistic decipherment and the fact that Maya writing contains syllabograms representing the sound of speech has also made us forget that Maya writing is first and foremost a logographic script, a script based on word signs (Grube 2021). Maya hieroglyphic writing has two classes of signs: Word signs, logographs, which refer to a particular word, and syllabograms, which do not denote any meaning, but only a combination of consonants and vowels, or simple vowels. In Maya writing, logographs represent words by depicting what is meant. Thus, there are logographs for "house," "jaguar," "king," etc., which are easily recognized as icons of these objects or beings, at least if one is familiar with Maya visual conventions. In terms of number, logographs are clearly predominant in texts. They render nouns and, to a lesser extent, verbs, while adjectives, prepositions, and particles did not have their own logographs due to their non-existent iconic referent (Grube 2021). Logographs provide a basic set of words that were important to the scribes of the Classic Maya. During the Preclassic, texts could be written almost exclusively by means of logographs, with the aid of only a minimal number of syllabograms for the occasional marking of possession or for verbal suffixes. In the Classic period, however, scribes became more demanding in terms of the representation of language. In particular, the recording of different verbal forms and more complex grammar was no longer possible with logographs alone. In addition, there were many semantic fields and abstract terms for which no logographs were available. This eventually led to an increase of the syllabic component of the texts. However, Maya writing remained primarily a logographic script.

Syllabograms, on the other hand, as phonograms, have no natural connection to the world of objects. Nevertheless, a look at the syllabic grid of Maya writing shows that syllabograms almost always have an iconic dimension and can be recognized as being derived from images of objects and beings. The explanation for the iconicity of syllabograms is related to the history of the development of Maya writing. Although the origin of many syllabograms is not yet known, several can be explained as acrophonic derivations (Houston 2000: 328; Houston 2012: 204; Kettunen and Zender 2019). Thus, the syllable cho is derived from the word choh, "lower jaw", the syllable 
mo is based on the eye of a Guacamaya parrot $\left(m o^{\prime}\right)$, and hu is derived from the head of an iguana, $h u j$ in most Mayan languages. In this acrophonic process, words lose the final, usually weak consonant and thus the relationship to their original meaning. The loss of meaning is often, but not always accompanied by the complete loss of the original image and a strong abstraction of the sign.

Logographs, however, have retained their pictorial quality throughout the entire period of existence of Maya hieroglyphs. Over the two millennia of its use, the proportion of logographs in the script has not diminished in favor of a reduction to a much smaller and, at first glance, more efficient set of syllabograms (Grube 1990). This proves that logographs are an essential feature of Maya writing. They provide an additional level of communication and understanding that goes beyond the linguistic level. Logographs connect the world outside the written texts with the written word and thus contribute to making the ontological boundary between word, image and object permeable. Logographs carried a decided semantic and existential weight, standing as evident proxies for perceptible things.

\section{Essential and generic personifications}

Bodies and body parts of living beings make up a large part of the repertoire of signs in Maya hieroglyphic writing, this applies to logographs as well as to syllabic signs. Even seemingly abstract signs can often be reconstructed as representations of body parts of humans or animals. Often these are pars-pro-toto representations, as the project "Text Database and Dictionary of Classical Maya" has identified them in the context of the reclassification of the signs for the revised sign catalog (Diehr et al. 2017; de la Iglesia et al. 2021). Fundamental to our new sign catalog is the distinction between sign (the abstract idea of a sign as a carrier of meaning) and graph (the realization in a particular context). Most signs can appear in different manifestations. For many signs there is a complex full form, but in very few cases it is used by the scribes. Instead, only parts of the signs are used, such as half, or only an upper element, sometimes only a certain prominent visual element. The dictionary project has investigated and systematically described the derivation of these graphs from the full forms of the signs (Prager and Gronemeyer 2018) ${ }^{1}$; it will not be analyzed in depth here. However, in the context of dealing with head variants, the differentiation between different discrete signs on the one hand and graph variants of signs on the other hand is important for the classification and understanding of head variants. This is best illustrated by examples: for the time unit haab "year", there were different spellings: there was the abstract sign 0548bv, but also the head variant 1034st, which is based on the representation of a bird's head with a human lower jaw (Figure 2). A comparison of the two signs clearly shows that they have nothing in common. Neither sign is related to the other in any way. We therefore classify both in our sign catalog as discrete signs that have the same 

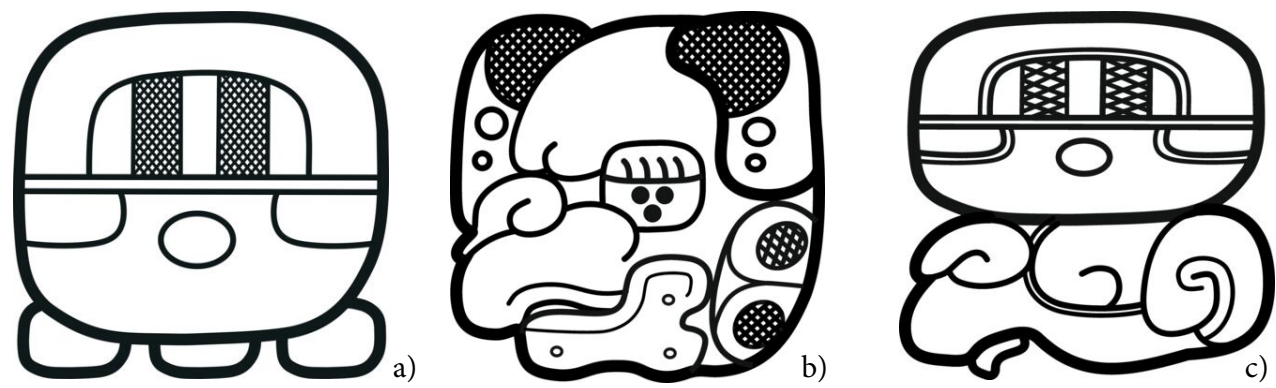

Figure 2: The distinction between graph variants and signs for HAAB “year". a) 0548bv, b) 1034st; c) $0548 \mathrm{pp}$ (Drawings by Christian Prager)

reading as a logograph (HAAB), but are each assigned independent sign numbers. However, there is also a variant of the logograph for HAAB, which is composed of the sign $0548 \mathrm{bv}$ as well as the head of a supernatural being. Since this variant is obviously only a personification of $0548 \mathrm{bv}$, it is listed in this case as a graph variant 0548pp in our sign catalog. Now, the two head variants for HAAB differ in that the bird's head variant 1034st is an independent sign that is in no way related to the graph variants for sign 0548 . The origin of the bird's head variant is still unclear and probably is related to the mythology of the origin of time units.

The distinction between sign and graph is also important for the systematic typology of animated signs. Basically, two types of animated signs can be identified in Maya writing: essential animated signs and generic animated signs, a distinction also suggested by Stephen Houston in his analysis of full-figure hieroglyphs (2014: $106)^{2}$. Essential animated signs are those whose faces and bodies are related to the word or concept or being to which they refer. Logically, these signs can only be logographs, because only logographs refer to words. Essential animated logographs are, for example, the many heads of supernatural beings that appear in the script. The head of the god K'awiil stands for the logograph K'AWIIL and thus for the deity itself, just as the head or body of a jaguar stands for the word BAHLAM, which means "jaguar". The head of a crocodile stands for the word AHIIN "crocodile", and the head of the god of drunkenness for the deity AKAN itself. But essential head variants can also represent actions and states of being which involve the human head, such as 0120bh K'AY "sing" and 0178st YA" "pain" (Figure 3). A large number of head variants still awaits decipherment.

Although all specific head variants are logographs, not all animations of logographs are necessarily essential. Logographs can also display non-essential, or generic personifications. These signs combine a geometric shape with a generic head or other body part. In its weakest form, animation only reshapes the left outline of a sign by adding a nose, a mouth, a forehead or a curl of hair. An example of this can be the logograph $\mathbf{K A B}$, whose basic shape is a geometric sign (Figure. 4a). 

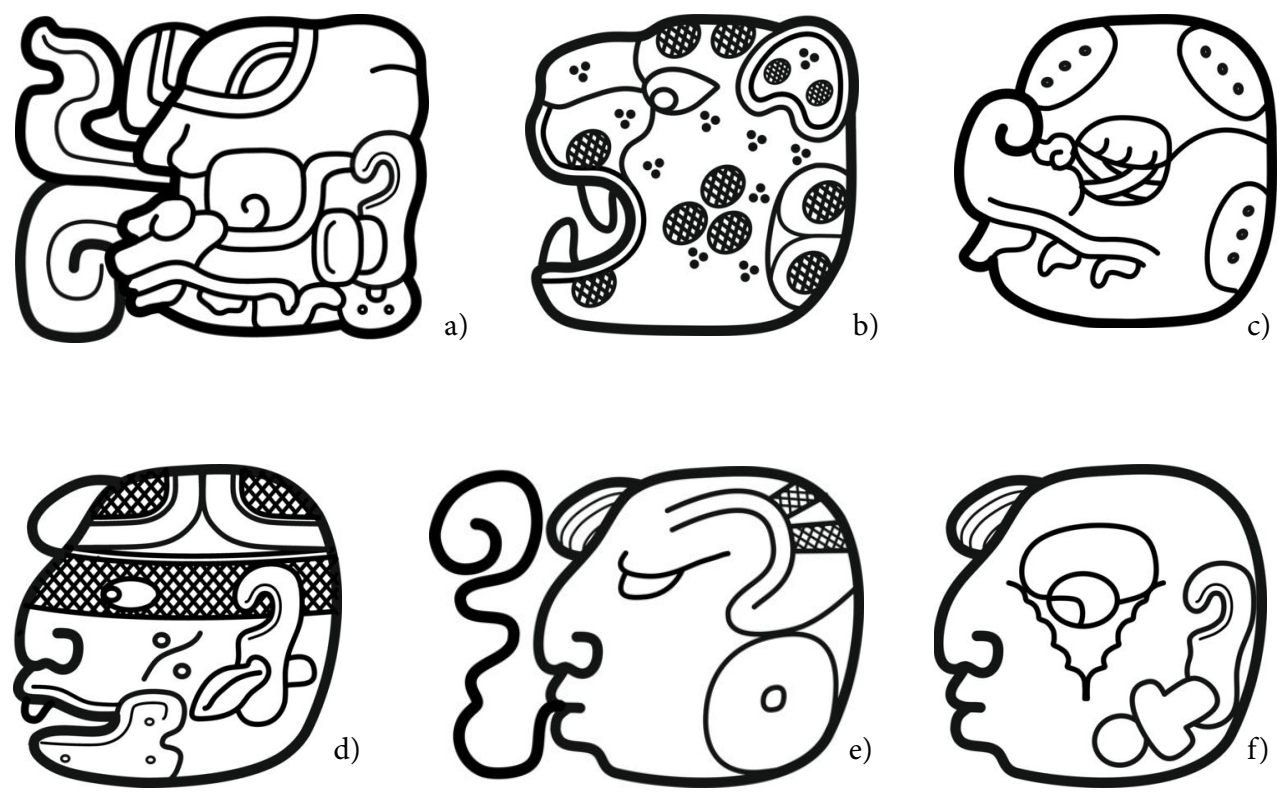

Figure 3: Head signs as logographs. a) K'AWIIL "god of lightning"; b) BAHLAM “jaguar"; c) AHIIN "crocodile"; d) AKAN "god of drinking"; e) K'AY "sing"; f) YA' "pain" (Drawings by Christian Prager).

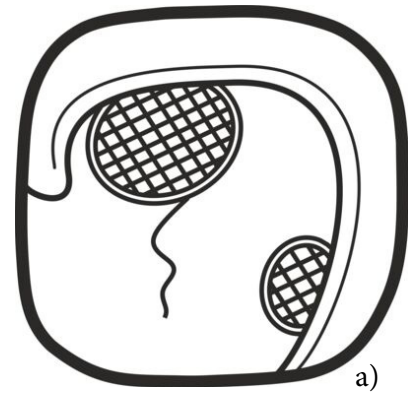

As an animated graph, the sign shows a profile head that contains the inner elements of the geometric sign (Figure 4b). The geometric and the animated version are different graphs of the same sign. The generic head attached to the sign contributes no additional value to the linguistic reading. Instead, the function of the generic animation was to communicate that not only the word "earth" was intended, but that the earth was regarded as an animate being endowed with life es-

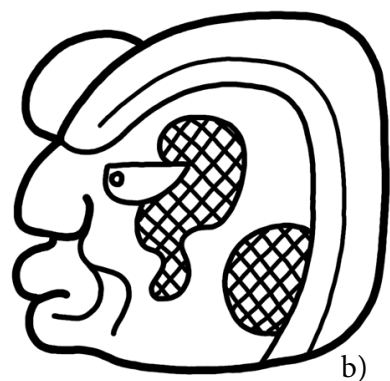
sence.

Other forms of generic animation show a non-specific head with an oversized snout, an equally oversized eye, and a large tongue hanging out of the corner of the mouth. These features are also found in numerous depictions of gods. Linda Schele and Mary Miller showed as early as 1986 in their Blood of Kings catalog that this generic supernatural head also

Figure 4: The generic personification of a logograph.

a) KAB "earth"; b) KAB "earth" (Drawings by Christian Prager and Nikolai Grube serves to suggest the presence of supernatural powers in sacred objects (Schele and Miller 1986: Fig. 21). In hieroglyphic writing we see examples of the per- 

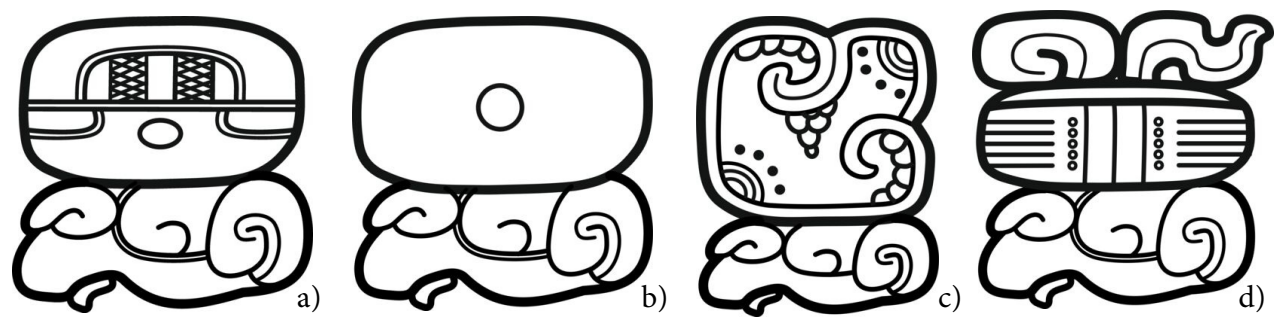

Figure 5: The animation of a logograph with a suffixed generic deity head. a) 0548pp HAAB "year"; b) PET "circle"; c) WITZ "mountain"; d) K'AHK' "fire" (Drawings by Christian Prager)

sonification of the signs for HAAB "year," PET "spindle whorl", WITZ "mountain," K'AHK' "fire," and TZ'AM "throne" (Fig 5). The fact that objects in Maya ontology have animacy and are considered to be imbued with agency has long been known (Schele and Miller 1986; Houston and Stuart 1996; Houston 2014.). Logographs that refer to things in the world are animated because they refer to a living world. The generic head of a supernatural was simply attached to a logograph, or the logograph was inserted into such a generic head, to indicate that it was filled with life force, that it had some kind of soul and energy. In this way, even objects that did not have an anthropomorphic or zoomorphic manifestation, such as a spindle whorl or a throne, could be given life when represented by a logograph.

\section{Animated syllables}

The animation of syllabograms is more complex because they do not entertain such an obvious link with the things and beings of the world. And yet, if we look at the syllabary, we see that many syllables have the form of heads of humans, supernaturals, or animals. The presence of anthropomorphic or zoomorphic syllabograms is the result of a historical process. These syllabograms developed out of logographs, which have lost their original meaning and transformed into representations of syllables in a process of acrophony. At some point, these signs may have been essential logographs, although it is currently impossible to trace their change of function diachronically $y^{3}$. Acrophonically derived syllabograms showing heads or body parts therefore constitute a category of signs somehow in between essential and generic personifications because of their particular diachronic development.

On the other hand, syllabograms with generic head forms can be identified much more easily. They can be recognized by the fact that they contain essential elements of the original graph and, as described above, only add a standardized personification head under the sign (Figure 6) or a simple face as a "façade" on the left side of the sign. There is no relationship between the face and the reading of the sign, because the face is usually the non-specific face of a young man, and in very few cases, that of a young woman. We can observe this process, for example, in 

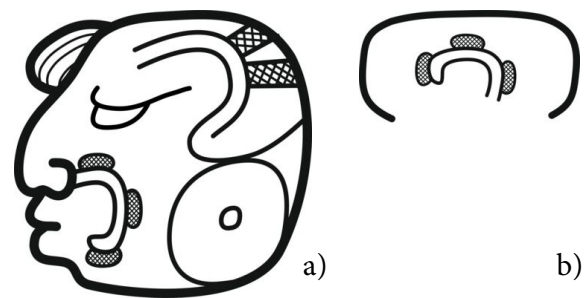

b)
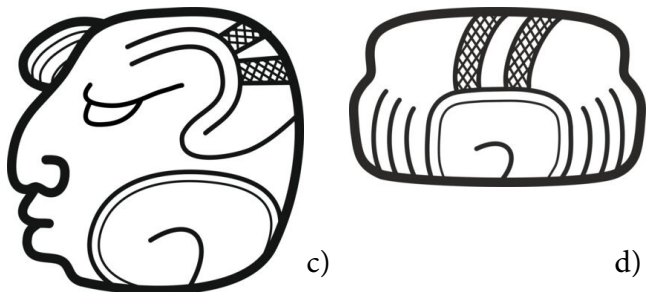

Figure 6: The animation of syllables with a generic head. a) $0021 \mathrm{hh} \mathrm{bu;} \mathrm{b)} 0021 \mathrm{vt} \mathrm{bu}$; c) $0017 \mathrm{hh} \mathbf{~ i}$;

d) 0017bh yi. (Drawings by Christian Prager)
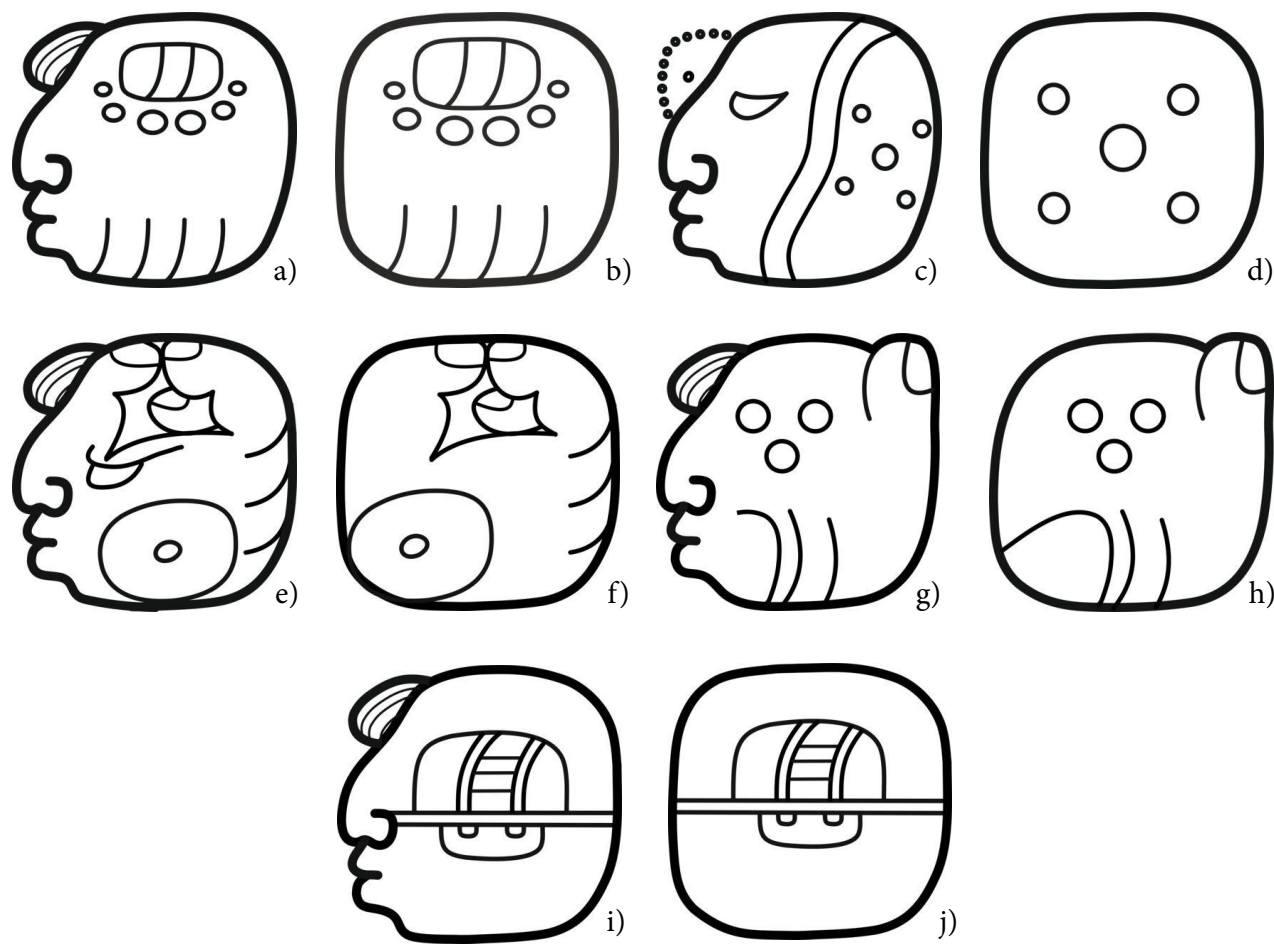

Figure 7: Syllabograms and their animation with an attached face. a) $0501 \mathrm{hh}$ ba; b) $0501 \mathrm{st}$ ba; c) $0585 \mathrm{hh} \mathrm{bi;} \mathrm{d)} 0585 \mathrm{st} \mathrm{bi}$; e) $0671 \mathrm{hh} \mathrm{chi,f)} 0671 \mathrm{st}$ chi; g) $0672 \mathrm{hh} \mathrm{ho;} \mathrm{h)} 0672 \mathrm{st} \mathrm{ho}$; i) $0679 \mathrm{hh} \mathrm{i}$; j) 0679st i (Drawings by Christian Prager)

the syllabic signs ba, bi, chi, ho, $\mathbf{i}, \mathbf{j a}, \mathbf{m a}, \mathbf{t a}, \mathbf{t z i}, \mathbf{l u}$, and others, which were given a nose, a mouth and eyes (Figure 7). Overall, however, these personifications are less common than essential personifications. Also, they do not yet appear in Early Classic inscriptions, making their first presence only in connection with the extensions and modifications of Maya hieroglyphic writing at the beginning of the Late Classic, which are probably a consequence of social and linguistic processes that changed Maya society during this period (Grube 1990: 82; 1994: 184-186). 
This form of personification of syllabograms impresses by its arbitrariness. There is no immanent connection between the face attached and the phonetic value of the sign. And yet, the artist who used such a sign felt the need not to employ a simple syllabogram, but to endow it with a face, thus indicating that language and its materialization in the form of writing were considered animated also on the level of the sound.

\section{The contexts of animated signs}

Animated signs appear already in the earliest examples of Maya writing. We see head variants in the texts of San Bartolo (Saturno et al. 2006), on the inscribed bone of Kichpamha (Gibson, Shaw and Finamore 1986), and also the perforatorsceptre from Uaxactun (Kováč, Jobbová and Krempel 2016), to name just a few texts from the Late Preclassic that have an archaeological context. In the context of Long Count dates, head variants appear as early as the oldest of these dates on Tikal Stela 29. Extremely playful head variants also appear in texts on ceramics, such as on a Lucha Incised blackware bowl found in an Early Classic burial in Structure C47 at Caracol (Chase and Chase 2014: 27, Figure 8). In these early texts, however, generic personifications are still extremely rare, and syllabograms with generic animations are still completely absent. However, it is precisely these generic personifications that provide overwhelming evidence for the idea of the animacy of signs.

The function of generic animation goes beyond the mere unspecific marking of "sacredness". This becomes especially clear by analyzing the contexts in which generically animated signs are particularly common. The scribe of Naranjo Stela 46, a monument unearthed only a few years ago (Martin et al. 2017) uses animated signs quite sparingly (Figure 9). However, the hieroglyph u-KAB-ji-ya, $u$ kabjiiy, which can be freely translated as "by his/her action/by his/her agency" (Schele 1982: 73; Martin and Grube 1994: 7), in this long inscription appears always in the animated form. The animation consists in a juvenile head attached to the left of the sign, therefore, this animation is a generic animation. The function of this compound is to introduce the name of the originator of an event. The personification of this logograph in this text lends weight to the idea of "agency", in particular since the few other personified signs in this inscription all are essential personifications. The generic animation of $u$ kabjiiy-compounds in Maya writing is very common and widespread and confirms the idea that animation was used very purposefully and deliberately by the scribes to augment texts with levels of meaning that go beyond the mere linguistic level.

One genre in which animated signs are particularly prevalent is in dedication texts for objects or buildings. The throne of structure $9 \mathrm{~N}-82$ from Copan, the House of the Scribe in the Sepulturas group is a good example for a text, whose sixteen glyph blocks are composed almost entirely with personified signs (Riese 1989; 

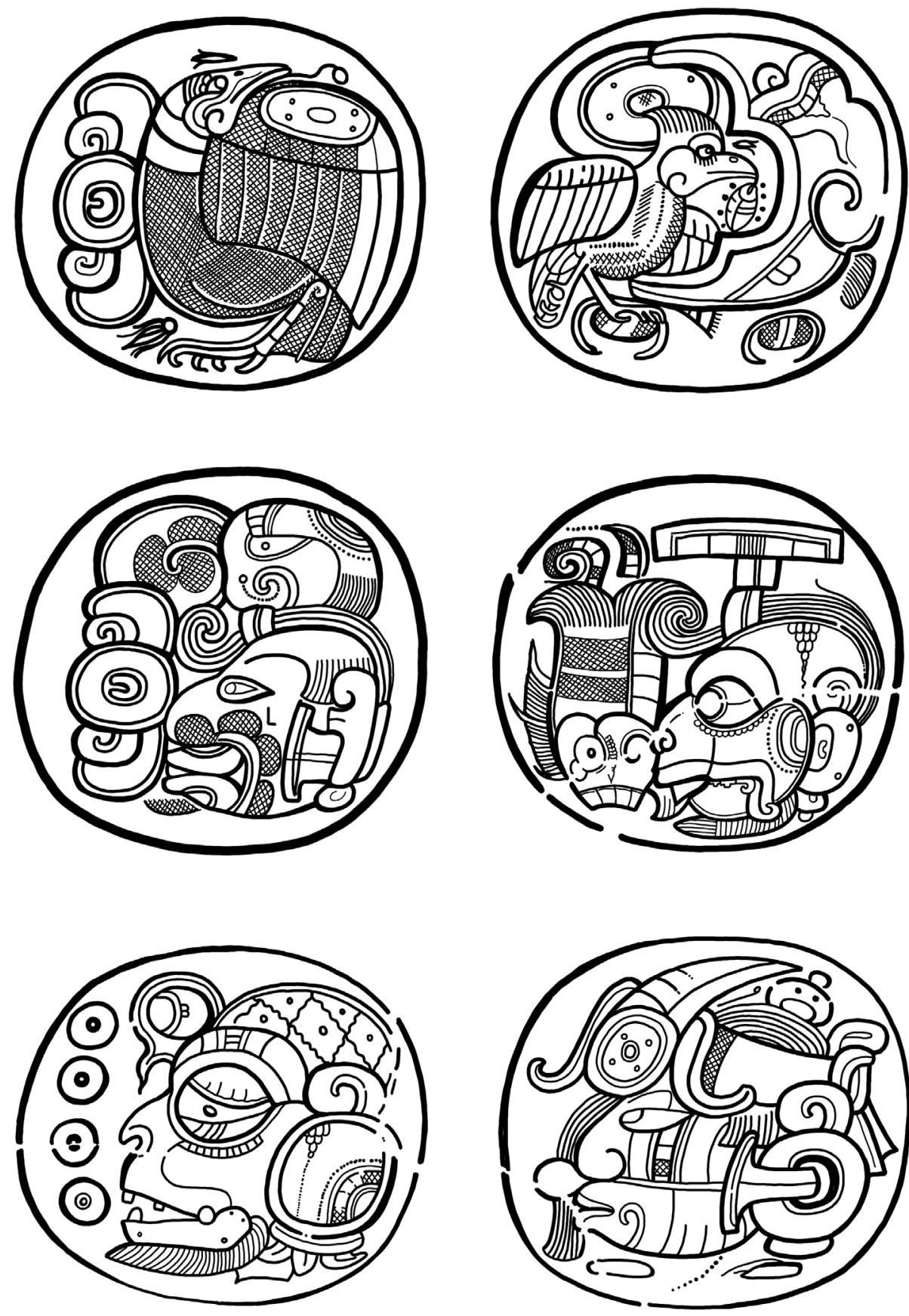

Figure 8: Hieroglyphic cartouches on a Lucha Incised blackware bowl from an Early Classic burial in Structure C47 at Caracol. The text reads yu-k'i-bi bi-?-la mu-yu-? ya-ka?-NAAH-hi CHAN-TE'-?AHK bi-ta-la-AJAW (Drawing by Nikolai Grube) 


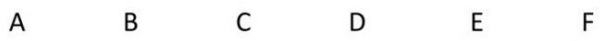

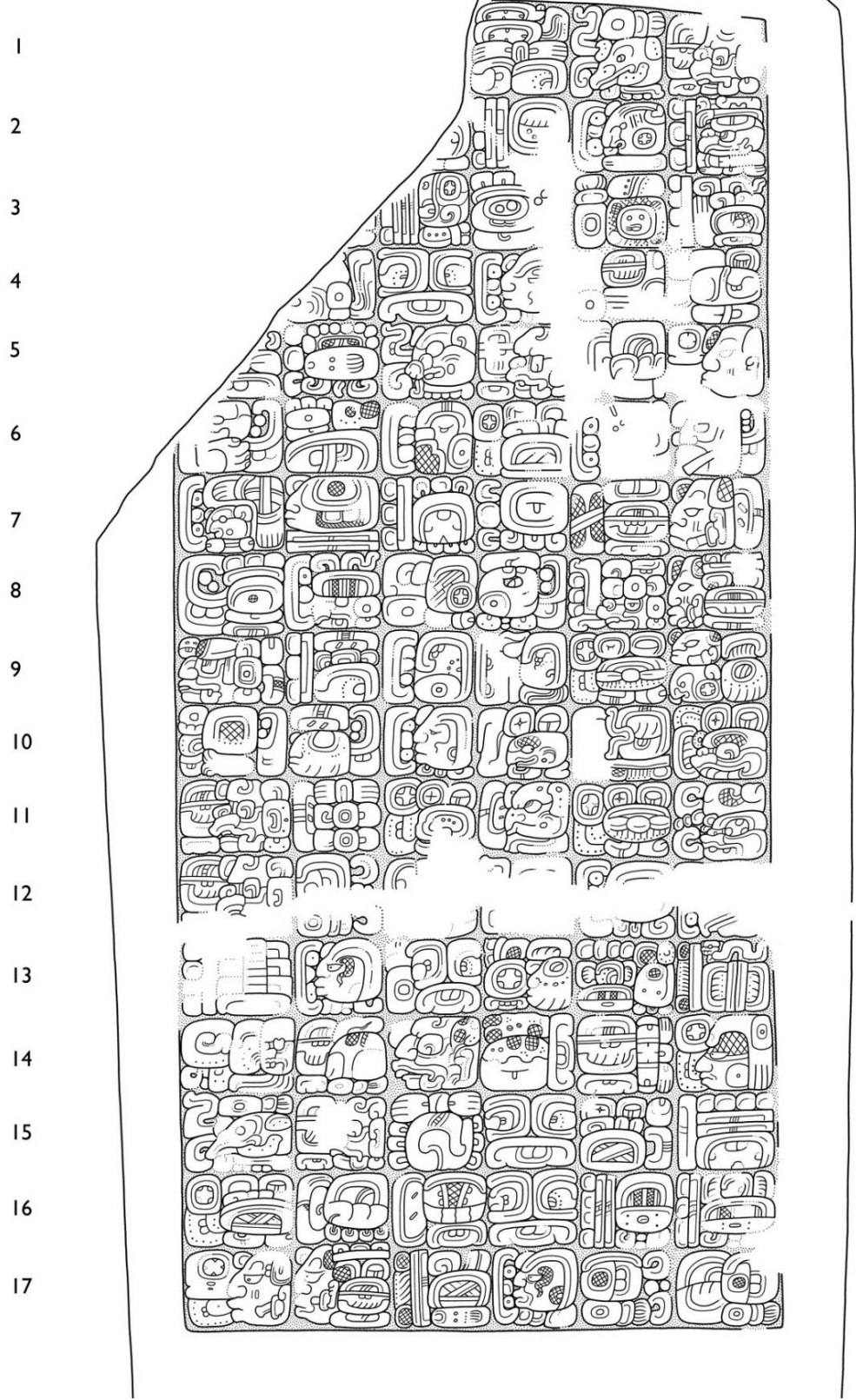

Figure 9: Naranjo Stela 46. The head variants of the KAB sign can be seen in B13, D4, C10 and D17. (Drawing by Alexandre Tokovinine in Martin et al. 2017) 


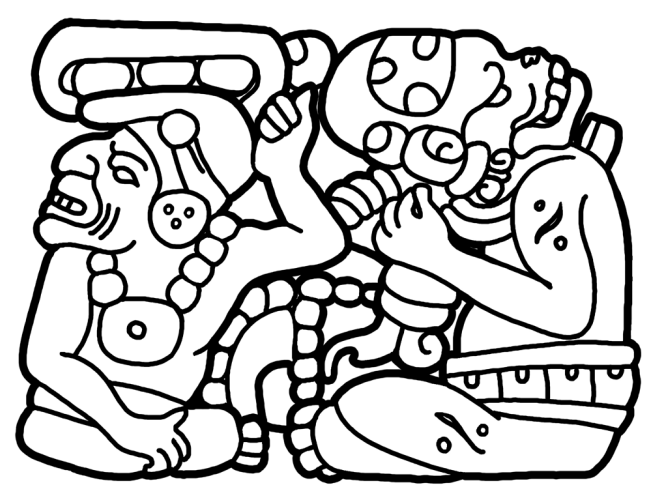

Figure 10: Part of the dedication phrase from the Sepulturas Bench from Copan (Drawing by Nikolai Grube)

Stuart 1992). The text deals with the dedication of the house as well as of the throne bench of the lord Makian Chanal. At the beginning of the dedication text, the verb $u$-t'ab-se "he lifts it" is written in such a way that the actual verb is a personified logograph, and the causative suffix formed by the syllable se is written as an animated syllabogram (Zender 2019: 31, Figure 10). The personification in this text is clearly in the tradition of personified and full-figure signs that began in Copan under the auspices of the king Waxaklajun Ub'aah K'awiil. The exceptionally animated throne text is also an indicator of the self-confidence and artistry of the scribe who inhabited the house.

Animated syllabograms are even more present in dedication texts on ceramics. These texts run as a band around the upper rim of a vessel opening and are largely standardized as Michael Coe already found out in 1973 (Coe 1973). Personified hieroglyphs are particularly common in dedication texts from the region of El Zotz' (Moot 2021). A polychrome vessel in this style shows a fascinating painted scene with Itzamnaaj, the maize god, the hero twins, and numerous other figures interacting in a scene of gift-giving (Kerr 7727, Figure 11). The dedication formula under the vessel's rim consists of fourteen glyph blocks, eleven of which are heads. We can see that the syllables yi, chi and tzi have been animated quite simply by inserting them into the generic face. The dedication formula is in stark contrast with the hieroglyphic captions below it, which use very few head variants representing spoken texts. This confirms that the animation of the dedication text was an important concern for the scribe. In fact, the use of head variants is a common feature of dedication texts on almost all ceramics. By animating the signs, dedication texts were endowed with agency. The signs are not only reproductions of language, they also act, they live and work and communicate between the artist, the supernatural forces, and owner or patron of the vessel. The application of a dedication formula to a ceramic object is what makes it a sacred object in the first place. The animated script functions as a transformative medium that changes the essence of the object on which it is placed.

As a result, texts became stages on which supernatural actors appeared and could be experienced sensually. Divine actors, and this includes objects endowed with life force and calendar periods, populate the texts and interact with each other. The fact that syllabograms were also personified in Maya writing shows that writing 


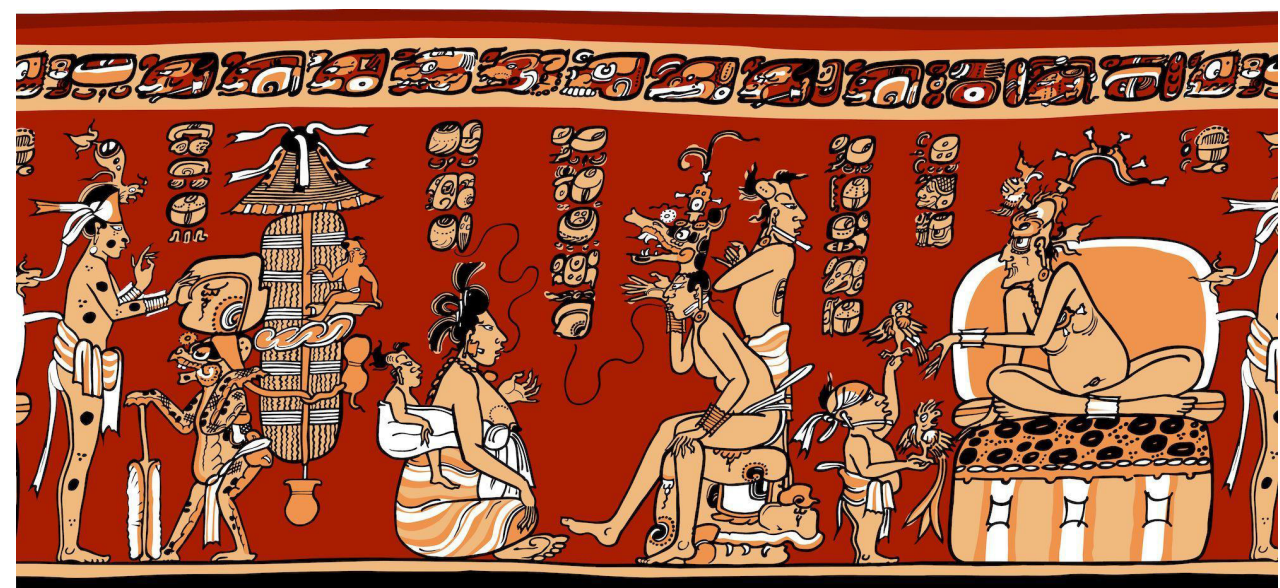

Figure 11: Rollout drawing of the design on the ceramic Kerr 7727 (Drawing by Dana Moot)

itself and individual syllabic sounds were considered to be endowed with vitality and with agency. However, this life force needed the artist to be born. Just as painters, sculptors and potters created the objects and thus made visible those forces inherent in the artwork, it was finally humans who could erase the written texts. In Aguateca (Stela 2) and Dos Pilas (Stela 16), the erasure of writing (chahkaj u tz'ibal) is mentioned as an outcome of the attack on Seibal. The destruction and killing of texts make clear that writing was not only animate, but also vulnerable and transient, just like human life.

\section{Notes}

1 The sign numbers refer to the new sign catalogue of the „Textdatenbank und Wörterbuch des Klasssichen Maya" project, which will be made available online soon. It was decided to maintain the numbers of the Thompson catalogue because they are well established. The two letter code after the sign refers to the particular graph variant of the sign, thus $0548 \mathrm{bv}$ identifies the sign as „bipartite vertical”, while 1034st stands for „standard”. The meanings of the innovative two letter codes are discussed in Prager and Gronemeyer 2018.

2 Houston calls the personifications that I call „essential” here „specific” and describes them this way: "The bodies fir with the creature or god whose face is shown". In contrast, he describes "generic" personifications: "They have no clear reference to a particular being other than a graceful, youthful face or, as the full-figuration erupts, a body, often clothed in simplest form but enough to hide the privates" (Houston 2014: 106).

3 Some signs which have been taken as evidence for syllabograms derived acrophonically from logographs actually are never used as syllabograms. The head of the pocket gopher 0757st, which appears in almost all published syllabaries with the reading ba is a good example. Based on the word for pocket gopher baah in most Mayan languages, the sign was used as a rebus for baah "first, head, image". It is impossible to find a single clear example for a purely syllabic use of this sign. In all contexts, it seems to function as a logograph with the readings mentioned before. In a revised syllabary, 0757st therefore should be removed as a ba syllable. 


\section{References}

Chase, Arlen and Diane Z. Chase (eds.)

2014 Ancient Social Integration in a Maya Neighborhood: Investigation of Adjacent Residential Complexes near Caracol's Epicenter: Caracol Archaeological Project Investigations for 2014: A Continuation of the 2012 and 2013 Research Focus. Report Prepared for the Belize Institute of Archaeology, University of Central Florida, Orlando.

Coe, Michael D.

1973 The Maya Scribe and His World. The Grolier Club, New York.

de la Iglesia, Martin, Franziska Diehr, Uwe Sikora, Sven Gronemeyer,Maximilian BehnertBrodhun, Christian Prager and Nikolai Grube

2021 The Code of Maya Kings and Queens: Encoding and Markup of Maya Hieroglyphic Writing. Journal of the Text Encoding Initiative Issue 14 |2021Selected Papers from the 2019 TEI Conference. https://doi.org/10.4000/jtei.3336

Diehr, Franziska, Maximilian Brodhun, Sven Gronemeyer, Katja Diederichs, Christian Prager, Elisabeth Wagner and Nikolai Grube

2017 Modellierung eines digitalen Zeichenkatalogs für die Hieroglyphen des Klassischen Maya: Ein neues Konzept zur Klassifikation von Schriftzeichen sowie der qualitativen Bewertung und Einstufung von Entzifferungshypothesen. In INFORMATIK 2017: Lecture Notes in Informatics (LNI), edited by Maximilian Eibl and Martin Gaedke: 1185-1196. Gesellschaft für Informatik, Bonn.

Gibson, Eric C., Leslie C. Shaw, and Daniel R. Finamore

1986 Early Evidence of Maya Hieroglyphic Writing at Kichpanha, Belize. Center for Archaeological Research, Working Papers in Archaeology, No. 2. The University of Texas at San Antonio.

Grube, Nikolai

1990 Die Entwicklung der Maya-Schrift. Grundlagen zur Erforschung des Wandels der Mayaschrift von der Protoklassik bis zur spanischen Eroberung (= Acta Mesoamericana, Bd. 3), Berlin: Verlag von Flemming.

1994 Observations on the History of Maya Hieroglyphic Writing. In Seventh Palenque Round Table, 1989, edited by Marle Greene Robertson and Virginia M. Fields: 177186. The Pre-Columbian Art Research Institute, San Francisco.

2021 „Ein Bild sagt mehr als tausend Worte“: Logographme in der Maya-Schrift. In: Der Text und seine Kulturen, herausgegeben von Andreas Kablitz, Christoph Markschies und Peter Strohschneider. DeGruyter, Berlin. (in press)

Houston, Stephen D.

2004 Writing in Early Mesoamerica. In The First writing: Script Invention as History and Process, edited by Stephen D. Houston: 274-312. Cambridge University Press, Cambridge.

2012 Maya Writing: Modified, Transformed. In: The Shape of Script: How and Why Writing Systems Change, edited by Stephen D. Houston: 187-208. School for Advanced Research Press, Santa Fe.

2014 The Life Within. Classic Maya and the Matter of Permanence. Yale University Press, New Haven. 
Houston, Stephen D./Andréas Stauder

2020 „What is a Hieroglyph?“, in: L'Homme 233(1), S. 9-44.

Houston, Stephen D., and David Stuart

1996 Of Gods, Glyphs, and Kings: Divinity and Rulership Among the Classic Maya. Antiquity 79: 289-312.

Kettunen, Harri, and Marc Zender

2019 On the Graphic and Lexical Origins of Maya Syllabograms. In Tiempo detenido, un tiempo suficiente: Ensayos y narraciones mesoamericanistas en homenaje a Alfonso Lacadena García Gallo. Edited by Harri Kettunen, María Josefa Iglesias Ponce de León, Felix Kupprat, Gaspar Muñoz Cosme, Verónica Amellali Vázquez López, and Cristina Vidal Lorenzo. Wayeb Publication Series, Vol. 1.

Kováč, Milan, Eva Jobbová and Guido Krempel

2016 The Legacy of an Early Maya King: Text, Imagery and Ritual Contexts of a Late Preclassic Cache from structure H-XVI Sub, Uaxactun. Mexicon XXXVIII (1): 9-29.

Martin, Simon, and Nikolai Grube

1994 Evidence for Macro-Political organization among Classic Maya Lowland States. www.mesoweb.com/articles/Martin/Macro-Politics.pdf

Martin, Simon, Alexandre Tokovinine, Elodie Treffel, and Vilma Fialko

2017 La Estela 46 de Naranjo Sa’al, Peten, Guatemala: hallazgo y texto jeroglífico. In XXX Simposio de Investigaciones Arqueológicas en Guatemala, 2016, edited by Bárbara Arroyo, Luis Méndez Salinas, and Gloria Ajú Álvarez, v. 2, pp. 669-684. Ministerio de Cultura y Deportes; Instituto de Antropología e Historia; Asociación Tikal, Guatemala

Miller, Mary, and Simon Martin

2004 Courtly Art of the Ancient Maya. Thames and Hudson, London and New York.

Moot, Dana

2021 Smoking Monkeys, Drunken Jaguars: A Formal Study of El Zotz-Style Ceramics. Unpublished MA thesis, California State University, Chico.

Prager, Christian M., and Gronemeyer, Sven

2018 Neue Ergebnisse in der Erforschung der Graphemik und Graphetik des Klassischen Maya. In Ägyptologische "Binsen”-Weisheiten III: Formen und Funktionen von Zeichenliste und Paläographie, edited by Gülden, Svenja A., van der Moezel, Kyra V. J., and Verhoeven-van Elsbergen, Ursula, pp. 135-181. Franz Steiner Verlag, Stuttgart.

Riese, Berthold

1989 The Inscription on the Sculptured Bench of the House of the Bacabs. In The House of the Bacabs, Copan, Honduras, edited by David L. Webster, pp. 82-88. Dumbarton Oaks, Washington, D.C.

Saturno, William, David Stuart, and Boris Beltran

2006 Early Maya Writing at San Bartolo, Guatemala. Science 311: 1281-1283.

Schele, Linda

1982 Maya Glyphs: The Verbs. University of Texas Press, Austin.

Schele, Linda and Mary Ellen Miller

1986 The Blood of Kings. Dynasty and Ritual in Maya Art. Kimbell Art Museum, Fort Worth. 
Spinden, Herbert

1913 A Study of Maya Art: Its Subject Matter and Historical Development. Memoirs of the Peabody Museum of American Archaeology and Ethnology 6. Harvard University, Cambridge.

Stuart, David

1992 Hieroglyphs and Archaeology at Copan. Ancient Mesoamerica 3(1):169-184.

Thompson, John Eric S.

1950 Maya Hieroglyphic Writing: An Introduction. Carnegie Institution of Washington Pub. 589. Washington, D.C.

Zender, Marc

2019 The Classic Mayan Causative. The PARI Journal 20(2):28-40. 